https://doi.org/10.15407/dse2019.03.047

УДК 314.5.063; 314.7; 314.743(479.22)

JEL CLASSIFICATION: J11, J61

\title{
L.E. MENABDISHVILI
}

$\mathrm{PhD}$ in economic, associate researcher

Ilia State University Institute of Demography and Sociology 0162, Georgia, Tbilisi, C. Cholokashvili str. 3/5

E-mail: lelamen@gmail.com

ORCID 0000-0003-3847-6250

\section{N.E. MENABDISHVILI}

$\mathrm{PhD}$ in economic, assistant researcher

Ilia State University Institute of Demography and Sociology

0162, Georgia, Tbilisi, C. Cholokashvili str. 3/5

E-mail: nanamen@gmail.com

ORCID 0000-0002-3577-4888

\section{N.A. GOMELAURI}

Associate researcher

Ilia State University Institute of Demography and Sociology

0162, Georgia, Tbilisi, C. Cholokashvili str. 3/5

E-mail: gomelaurinino@yahoo.com

ORCID 0000-0003-4796-4221

\section{MIGRATORY DISPOSITION OF GEORGIA'S STUDENT YOUTH}

The article is based on the sociological research conducted among students with direct participation of the authors. The aim of the research is to study migratory disposition, motives, goals and objectives of the students. Three groups of the students who wish to go abroad stood out: those who only wish to study, those who wish to mix studying and working and the students who only wish to work abroad. A comparative analysis on some of the data in regard to the research which was done ten years ago is carried out. It became clear that in consequence of the limited opportunities of employment within the country, as well as constricted labor income and higher competitiveness of those persons who received education abroad, the motivation to leave the country is growing among the students. The majority of students oriented toward emigrating want to combine studying and working abroad. Subsequently, they choose universities mainly on the basis of the mentioned criterion. The students mostly plan on continuing their studies on a higher level with the same or related profile. One of the important factors 
for the youth in finding a job abroad is to work with their profession, and then to have a high salary. The higher the salary of these students in their homeland, the higher is their demand in terms of the salary which they think they ought to receive in emigration. If a decade ago illegal employment was approved and acceptable, now the attitude has changed drastically. The majority of the students hold a negative position toward this issue, even if they cannot find a job legally. A fairly noteworthy tendency has appeared in that among the students willing to go abroad, the number of those who do not plan on returning back to homeland has increased 1.4 times. Certain portion of these students will decide whether to come back or not based on how they will realize their aspirations and goals abroad. According to the results of the research, we think that an active demographic policy ought to be implemented, which should be carried out in parallel to those challenges that our country faces today.

Keywords: emigration, migratory disposition, labor emigration, educational emigration.

\section{Л.Е. Менабдишвілі}

канд. екон. наук, асоц. дослідн.

Інститут демографії та соціології Державного університету Ілії

0162, Грузія, м. Тбілісі, вул. К. Чолокашвілі, 3/5

E-mail: lelamen@gmail.com

ORCID 0000-0003-3847-6250

\section{Н.Е. Менабдишвілі}

канд. екон. наук, асист.-дослідн.

Інститут демографії та соціології Державного університету Ілії

0162, Грузія, м. Тбілісі, вул. К. Чолокашвілі, $3 / 5$

E-mail: nanamen@gmail.com

ORCID 0000-0002-3577-4888

\section{Н.А. Гомелаурі}

асоц. дослідн.

Інститут демографії та соціології Державного університету Ілії

0162, Грузія, м. Тбілісі, вул. К. Чолокашвілі, 3/5

E-mail: gomelaurinino@yahoo.com

ORCID 0000-0003-4796-4221

\section{МІГРАЦІЙНА УСТАНОВКА СТУДЕНТСЬКОЇ МОЛОДІ ГРУЗІЇ}

Стаття заснована на соціологічному дослідженні проведеному серед студентів за безпосередньої участі авторів. Що стосується мети дослідження, вивчені міграційні установки, мотиви, цілі і завдання еміграції студентів. Виділено три групи студентів, які хочуть виїхати за кордон: ті, хто тільки бажає вчитися, ті, хто бажають поєднати навчання і роботу, і студенти, які бажають тільки працювати. Виконано порівняльний аналіз деяких даних з результатами досліджень, які були проведені десять років тому. Виявлено, що внаслідок обмеженої можливості працевлаштування, а також низьких трудових доходів і вищої конкуренції серед людей, які отримали освіту за кордоном, зростає мотивація студентів покинути країну. Серед студентів, орієнтованих на еміграцію, більшість поєднує навчання за кордоном і трудову діяльність, і переважно цей критерій є основним у виборі вищого навчального закладу. Студенти найчастіше планують продовжити навчання на більш високому рівні з тим же або пов'язаним з ним профілем. Одним з найважливіших факторів працевлаштування для молоді є робота за фахом, а потім і висока оплата праці. Чим вище зарплата цих студентів на батьківщині, тим вище їх запит на зарплату, яку вони бажають отримувати в еміграції. Якщо десять років тому нелегальне працевлаштування схвалювалося і було прийнятним, то зараз ситуація різко змінилася. Більшість студентів негативно ставиться до цього питання, навіть якщо вони не зможуть працювати легально. Виникла досить примітна тенденція: серед студентів, що бажають виїхати за кордон, число тих, хто не планує повертатися на батьківщину, збільшилося в 1,4 раза. Певна частина цих студентів буде вирішувати повертатися на батьківщинучи ні, грунтуючись на тому, як вони будуть реалізовувати свої прагнення і цілі за кордоном. Згідно з результатами дослідження, ми вважаємо, що необхідно проводити активну демографічну політику, яка повинна здійснюватися паралельно з тими викликами, з якими сьогодні стикається наша країна.

Ключові слова: еміграція, міграційна установка, трудова еміграція, навчальна еміграція. 


\section{Л.Э. Менабдишвили}

канд. экон. наук, ассоц. иссл.

Институт демографии и социологии Государственного университета Ильи

0162, Грузия, г. Тбилиси, ул. К. Чолокашвили, 3/5

E-mail: lelamen@gmail.com

ORCID0000-0003-3847-6250

\section{Н.Э. Менабдишвили}

канд. экон. наук, ассист.-иссл.

Институт демографии и социологии Государственного университета Ильи

0162, Грузия, г. Тбилиси, ул. К. Чолокашвили, 3/5

E-mail: nanamen@gmail.com

ORCID 0000-0002-3577-4888

\section{Н.А. Гомелаури}

ассоц. иссл.

Институт демографии и социологии Государственного университета Ильи

0162, Грузия, г. Тбилиси, ул. К. Чолокашвили, 3/5

E-mail: gomelaurinino@yahoo.com

ORCID 0000-0003-4796-4221

\section{МИГРАЦИОННАЯ УСТАНОВКА СТУДЕНЧЕСКОЙ МОЛОДЕЖИ ГРУЗИИ}

Статья основана на социологическом исследовании проведенном среди студентов при непосредственном участии авторов. Что касается цели исследования, изучены миграционные установки, мотивы, цели и задачи эмиграции студентов. Выделены три группы студентов, которые хотят уехать за гранииу: те, кто желают только учиться, те, кто желают совместить учебу и работу, и студенты, которые желают только работать. Выполнен сравнительный анализ некоторых данных с результатами исследований, которые были проведены десять лет назад. Выявлено, что вследствие ограниченной возможности трудоустройства, а также низких трудовых доходов и более высокой конкуренции среди людей, которые получили образование за рубежом, растет мотивация студентов покинуть страну. Среди студентов, ориентированных на эмиграцию, большинство совмещает обучение за рубежсом и трудовую деятельность, и чаще всего, этот критерий является основным в выборе высшего учебного заведения. Студенты преимущественно планируют продолжить обучение на более высоком уровне с тем же или связанным с ним профилем. Одним из важнейших факторов трудоустройства для молодежи является работа по специальности, а затем и высокая оплата труда. Чем выше зарплата этих студентов на родине, тем выше их запрос на зарплату, которую они желают получать в эмиграции. Если десять лет назад нелегальное трудоустройство одобрялось и было приемлемым, то сейчас положение резко изменилось. Большинство студентов негативно относится к этому вопросу, даже если они не смогут работать легально. Возникла довольно примечательная тенденция: среди студентов, желающих выехать за гранииу, число тех, кто не планирует возвращаться на родину, увеличилось в 1,4 раза. Определенная часть этих студентов будет решать - возвращаться на родину или нет, основываясь на том, как они будут реализовывать свои стремления и цели за рубежом. Согласно результатам исследования, мы считаем, что необходимо проводить активную демографическую политику, которая должна осуществляться параллельно с теми вызовами, с которыми сегодня сталкивается наша страна.

Ключевые слова: эмиграция, миграционная установка, трудовая эмиграция, учебная эмиграция.

Description of the research problem and relevance of the article. Nowadays, the Georgian economy offers its citizens relatively limited opportunities for employment, labor income, social assistance or improved quality of life. This unsolved problem fosters labor emigration and essentially increases the labor migratory motivation in the youth. In addition to this, the process of globalization has expanded the area in terms of receiving education. We should assess as progressive the fact that youngsters have a chance to receive education wherever they want and are not constricted by sticking to only their own country. Oftentimes, life and education abroad are funded by international educational programs. This makes it favorable 
and attractive yet for the students to receive education abroad. Continuing education abroad is often accompanied by employment in the given country, which, in turn, indefinitely prolongs emigratory life.

Georgia is among those countries where the external migration plays an important role in forming the population. Since the second half of the previous century, under conditions of a relatively high natural increase, the negative net external migration had an impact on the growth rates of the quantity of the country's population. This process has assumed especially dramatic character since 1992 until today, when low natural increase can no longer compensate for high negative net migration, and thus the decline in Georgian population becomes noticeable [1]. In a mere twelve years (in the interim period between the 2002 and 2014 general population censuses) the population of Georgia decreased by $15 \%$, that is, by 657731 inhabitants. From 2002 until 2014 the quantity of the emigrated persons from Georgia amounted to 1.15 million, whereas the quantity of the immigrated persons in Georgia reached 875000 . This figure includes foreigners as well, although, the majority of them are Georgians who returned back to their homeland [2].

According to the last general population census of the country in 2014, there were 223 depopulated villages in Georgia. Together with decline, the Georgian population is also characterized by the tendency of aging. One of the factors which contribute to the aging process is emigration. According to the data of Geostat, 98935 inhabitants departed from the country in 2018 (among them 56116 males and 42819 females). The net migration is negative similar to the previous years and amounts to 10783 inhabitants. Based on the age-related data, the complete picture of the emigrants is the following: $0-14$ age group - 9880 inhabitants, 15-64 age group - 85652 inhabitants, and 65 and above age group - 3403 inhabitants [3].

People of the fertility age are the main contingent of emigrants. This has had a significant effect on the quantitative change which occurred in the sex-age division of youth. One of the important reasons behind sex-age disbalance is said to be an abundance of young males compared to young female emigrants. Intensive migratory processes brought the population reproduction of Georgia to a reduced regime. Currently, the country is on the list among the dying nations. It is vitally important to carry out effective demographic policy within the country, which makes it necessary to study the issue fundamentally. Statistical data represent the severity of the issue only on the surface. It is significant to conduct a sociological research which will deeply study the population's disposition and will enable us to make predictions.

Georgian scientists-demographers have always expressed great interest in studying migratory processes. Many researchers have been conducted with regard to this issue and the results have been published in the domestic, as well as international journals by such famous scientists as: A. Sulaberidze, M. Tukhashvili, M. Shelia, I. Archvadze, A. Totadze, N. Chelidze, G. Tsuladze, E. Menabdishvili, T. Zubiashvili, I. Badurashvili, etc.

The aim of the article and innovation character is to study migratory disposition, motives, and goals of the student youth. It attempts to figure out to what degree they are ready for emigration. When do they plan on going abroad and how much time are they going to spend there approximately. Our choice fell on the students because they are the members of the generation that create the country's future. The future of our country is dependent on them in terms of surviving physically, as well as with respect to political, economic, social and cultural development. We will use the results of the sociological research in order to characterize the students' migratory disposition. The mentioned research was conducted by the staff of the Institute of Demography and Sociology of Ilia State University at state and private universities of three Georgian cities: Tbilisi, Kutaisi and Batumi. 1250 students 
from the junior and senior levels were interviewed. The scientific novelty of the article is that it is based on the first results of the survey done among the students since implementing the visa regime in the country, and it enables projections of the nearest period. A comparative analysis of some of the issues with a survey conducted ten years ago is presented. The following work demonstrates the tendency of the growth of outflow from the country and decline in the tendency of return back to homeland.

Research methods. We chose the three largest cities of Georgia for the purpose of conducting the research: Tbilisi, Batumi and Kutaisi. During 2017-2018 study, 143808 students at state as well as private universities and colleges were registered. Due to the fact that freshmen and sophomore students do not yet have clear goals set out at their stage of studying, we chose junior and senior students as the target audience for our research. We used the quantitative method for the research and determined the number of selected students to be at 1250 for representativeness. The respondents were picked using the selection principle of probability. The research was conducted through the questionnaire which was specially put together including the issues of migration. The questionnaire was anonymous and contained demographic data, the questions pertaining to the migration were divided into two blocks: one dealt with the external migration and the other with internal. The questions were of open as well as of closed type and the respondents could freely express their position and opinion.

Basic results of the research. Disposition of education. In accordance with the data of the 2014 general population census, within $11 \%$ a member of a family resides abroad in order to receive education. $73.4 \%$ among them are representatives of both sexes within the age group of 20-39 - altogether 7122 persons [3].

The data of the National Statistics Office of Georgia on the quantity of the students who went abroad to get educated according to study years are not accurate. These data are given to the state by universities and they only reflect the number of those students who left by using exchange programs. Therefore, it does not include the quantity of those students who left on account of their own initiative. If we take into consideration the students' attitudes, the number of the students who went abroad on their own initiative exceeds the number of those who left by using the exchange programs.

From among the interviewed students $42 \%$ intend to go abroad. $59 \%$ plan on leaving within the nearest three years. This figure is 1.4 times higher than the number of those students who plan to do the same after the three year period. Among those who wish to go abroad, the number of women exceeds 1.3 times that of men. Amid those men who plan on going abroad, the number of those who plan to do so within the next three years exceeds 1.6 times the number of those who intend to leave after the three year period. The same figure among the women exceeds 1.3 times the figure of those who want to go abroad after the next three year period.

For the majority of the mentioned students the main reason behind going abroad is to continue studying $-84.2 \%$ (31.8\% among them only intend to study, whereas $68.2 \%$ plan to mix work with studying). The quantity of the students who plan on departing only for labor activities lags behind 5.6 times the quantity of those who only wish to study there and drops back 3.6 times the quantity of those who wish to mix labor and studying. The same figure is 1.7 times less than the quantity of those students who wish only to study abroad.

For each and every student studying abroad is associated with the first step taken toward a successful future, because on account of the situation on the labor market those people who receive education abroad are more competitive than those who do so in Georgia. The best way to go abroad in order to study is to take part in the exchange programs. Only a small portion of the interviewed students (3.7 \%) goes abroad by participating in the exchange 
Table 1. Distribution of the students, who plan on going abroad for studying, according to the choice of a university or college, $\%$

\begin{tabular}{|l|c|c|}
\hline \multicolumn{1}{|c|}{$\begin{array}{l}\text { Have you chosen the university where you are going } \\
\text { to continue studying? }\end{array}$} & \multicolumn{2}{c|}{ Reason for going abroad } \\
\cline { 2 - 3 } & Studying & Studying and working \\
\hline Yes, I have & 36.0 & 64.0 \\
\hline $\begin{array}{l}\text { I have sent my documents to several universities and am } \\
\text { waiting for reply }\end{array}$ & 41.2 & 58.8 \\
\hline No, I have not & 30.3 & 69.7 \\
\hline
\end{tabular}

Source: sociological research of the Institute of Demography and Sociology of Ilia State University, 2018.

program. 1.5 times less of them have obtained a grant. Consequently, those youngsters who have firmly decided to carry on studying abroad and could not secure a place within the international exchange programs seek out other ways to depart. There are various programs to obtain funding for those who wish to go abroad, amidst them are foreign educational funds, therefore, the road is open for such students.

After making a decision, they ought to carry out effective measures in order to bring the mentioned decision to its end. In this regard, the matter in question is choosing a university or college. When analyzing the issue from the above-mentioned standpoint, the respondents were divided into three groups: the first group encompassed those students who knew exactly where they would continue studying in the near future; the second group included those respondents who had sent their documents to several universities and were waiting for the response, because of which they could not name the chosen university in the process of research; and the third group contained those students who only expressed their wish to study abroad and had not taken any decisive steps toward achieving this goal. From among the allotted three groups, the most respondents ended up in the latter group. The number of such students exceeds 1.8 times the number of the students together in the remaining two groups, eclipses 2.2 times the number of only the first group, and 11.3 times the number of only the second group's respondents.

To identify those criteria that determined the choice of a concrete university on the part of students, we offered a list to the respondents. However, if there was no fitting option within the list, they could name it personally. As the gathered data demonstrated, while choosing universities/colleges the respondents attached the least importance to tuition fees and considered as the most significant the possibility to mix studying and working. The last criterion exceeds 2.2 times all the afore-mentioned criteria taken together, and 12.9 times only the criterion of choosing universities/colleges because of a cheap tuition fee.

Inasmuch as the youngsters who receive education abroad are more competitive than those who receive it in Georgia - are taken to Georgia, it is completely logical that while trying to determine the reasons for departing abroad, the following was one of the highest figures: people who get educated abroad have a higher chance and prospects to find a job in Georgia - $34.8 \%$.

Taking into account that a person who has studied abroad is more competitive on the labor market, it is considered that the country does not have a high-quality education compared to abroad. Therefore, the most frequent reason mentioned by the going students that they will get more high-quality education abroad (46.6\%) can be assumed as the necessary condition to successfully get employed in homeland. 
Table 2. The main criteria for choosing universities / colleges abroad according to the sex of the respondents, $\%$

\begin{tabular}{|l|c|c|c|}
\hline \multicolumn{1}{|c|}{ Criteria } & Male & Female & Total \\
\hline Opportunities for training & 21.3 & 10.3 & 14.8 \\
\hline Winning a scholarship competition & 5.3 & 3.7 & 4.3 \\
\hline Having the European system for transferring credits & 8.5 & 9.6 & 9.1 \\
\hline Taking part in an exchange program & 8.5 & 6.5 & 7.4 \\
\hline Relative cheapness at the place & 5.3 & 2.2 & 3.5 \\
\hline Opportunities to mix studying and working & 39.4 & 49.3 & 45.2 \\
\hline Opportunities to take part in various scholarship programs & 11.7 & 18.4 & 15.7 \\
\hline
\end{tabular}

Source: sociological research of the Institute of Demography and Sociology of Ilia State University, 2018.

Table 3. Distribution of students in accordance with the desired study level, $\%$

\begin{tabular}{|l|c|c|c|}
\hline On what level do you plan to continue studying abroad? & Male & Female & Total \\
\hline Short-term program & 14.8 & 15.0 & 14.7 \\
\hline Baccalaureate & 9.4 & 9.6 & 9.6 \\
\hline Master's & 63.3 & 62.0 & 62.8 \\
\hline Doctorate & 8.6 & 12.9 & 10.9 \\
\hline Residency & 3.9 & 0.5 & 2.0 \\
\hline
\end{tabular}

Source: sociological research of the Institute of Demography and Sociology of Ilia State University, 2018.

To conclude, the decision of the students to study abroad is directly linked with the prospect of finding a job in their homeland. However, there was such category of respondents for whom studying abroad represents a "green card" to find a job and live as emigrants $-12.4 \%$.

The majority of the students who want to go abroad plan to carry on studying on a higher level, although, there were such among the respondents who wanted to study again on the baccalaureate level or take short-term programs. However, the quantity of the latter category is 3 times less than the quantity of those who have decided to study on the higher level (master's, doctoral degree, and residency).

Only a small quantity of the students $(5.0 \%)$ think about changing their profession while studying abroad. The share of those students who intend to continue studying abroad to expand knowledge of their already chosen profession is more than half. A little more than one-fifth of them plan to carry on studying a related profession, whereas $15.4 \%$ want to choose a broader profile.

In conjunction with the data of the National Statistics Office of Georgia, the majority of the students who departed abroad during 2015-2016 study year went to Germany. Poland came in second, and the rest of places were taken by the Baltic countries. Only four students went to USA. According to our sociological research, the student respondents are ready to leave for basically the following countries: Germany (37.2\%), the USA (16.8\%), the United Kingdom (11.4\%), Italy (5.4\%), France and Russia (3.4\%). 
Labor disposition. It is difficult for many youngsters to find a job in Georgia and oftentimes the search for the job yields no results. According to the 2014 population census, 16.1 $\%$ of the workforce is unemployed. The level of unemployment is higher among women than among men. Within the age group of 15-25 there are 120000 thousand youngsters that are not employed, which is $29.6 \%$ of the youth [3].

Nowadays, the unemployment level is 2.3 times higher within the age group below 25 compared to the unemployment level of the older population (therefore, the unemployment level of the former age group is $28.9 \%$, where the same figure for the latter group is $124 \%$ ). In contrast to the rest of the population, the level of economic activeness is 1.6 times lower among the youth and the level of employment is 2 times lower. Amid the youth aged below 25 , only every third of them is employed [4].

The indicator of unemployment is the highest among the youth who possess only secondary or school education. Taking into account the data of the last population census, only one-third of them were employed. Among the youth who possess higher education the level of unemployment was at $23.3 \%$ [5]. This is a problem which substantially increases the motivation to resort to labor emigration among the youth.

Student respondents mention that the reason for their going abroad to work is mostly the lack of prospects to find a suitable job in their own country $(47.1 \%)$.

Sociologists attach a large significance to having a work place, as work is not only a source of income, but also an important part of one's identity, perception and purpose. A big part of one's identity is formed by his/her job. Even when a person is not satisfied with his/her own job, they still form a big part of their identity with the help of their work [6]. At the same time, it must be considered that the majority of the employed people spend, on average, between 35 and 45 hours or more at their work place weekly.

After conducting the survey by the Institute of Demography and Sociology of Ilia State University, it became clear that $44.5 \%$ of the student respondents mix studying and working. Despite this, a certain portion of them still think about emigrating abroad in order to work. One of the important conditions in regard to the desired work is associated with salary. Sociologists think that social contact is at the second place for humans only because they place the salary at the first place as the reason for work [6]. Labor income ought to be such as to satisfy a family's economic goal - meeting elementary needs; providing - expanding, improving living conditions; ensuring children's good future. A significant part of the Georgian families are not able to accomplish all of the above.

As a consequence of a low salary, within the next three years nearly every fourth student intends to leave abroad. It is noteworthy that this figure exceeds 1.4 times the data received from the research conducted among the students ten years ago (17.4\%) [7].

The students agree to work abroad if their salary will be at minimum 1000 US dollars. This sum exceeds 2.5 times the average income in Georgia and five times and more the factual income of those students who are employed in their homeland [4]. The research showed the tendency that the higher the student's income within the homeland, the higher their demands with regard to the income they expect to get in emigration.

In spite of the fact that the labor income is one of the important factors for students, they still consider it advantageous to work using their own occupation. The number of those students who placed work by occupation at the first place is 2.8 times more than the number of those for whom the principal factor is a job with a high income. On top of the above, the demand for the high income job coincides with the demand for the job that offers normal labor conditions. 
Table 4. Necessary criteria for labor activity abroad amid students, \%

\begin{tabular}{|l|c|}
\hline \multicolumn{1}{|c|}{ What kind of job is the most acceptable to you while residing abroad? } & $\%$ \\
\hline Working with my occupation & 49.8 \\
\hline High-income job & 17.3 \\
\hline Job with normal working conditions & 17.3 \\
\hline Job where my rights will be protected & 13.1 \\
\hline Any kind of job & 2.5 \\
\hline
\end{tabular}

Source: sociological research of the Institute of Demography and Sociology of Ilia State University, 2018.

Students' attitudes and demands toward legal work have changed significantly. A little over a decade ago a substantial portion of the population thought it important to find a job abroad and paid little or no attention to its legality. Our research has clearly demonstrated that the students have developed a sharply negative attitude toward the illegal work. $62 \%$ of the interviewed students do not plan to work illegally even if they cannot find the legal job abroad.

Something that causes a vital interest is whether the departing youngsters intend to return to their homeland. Women were more inclined to come back. Their number exceeded 1.7 times the number of men. $3.9 \%$ do not plan to return to homeland at all. Among them, the number of men exceeds 1.5 times the number of women. A large portion of the respondents does not have a distinct position with regard to the mentioned issue. They intend to make a decision after they finish studies. Presumably, the issue of their return is associated with the opportunity of being employed abroad. There is a high chance that, in case of getting lucky, they will, in a better scenario, postpone their plans to return back to the homeland. Within this group the quantity of women is 1.4 times more than that of men [8].

As we have already mentioned, $3.9 \%$ of the students intend to leave the country for good. This figure is 1.4 times higher than the figure received from the previous sociological research ten years ago (2.85) [7], so the employment of the youth remains an unsolved problem in the country. In turn, the said unsolved problem contributes to labor emigration. Intensive migratory flows per se have a large influence on the demographic development of the country. In our opinion, the situation is critical and it is essential to implement an active demographic policy, which ought to be carried out in parallel to the country's economic rise.

Conclusions. Overcoming poverty and unemployment remain the primary challenges in Georgia. Furthermore, those individuals who received education abroad are more competitive than those who did so in Georgia. These facts facilitate migratory processes and the youth's attitude toward going abroad is gradually strengthened. The wish to mix studying and working abroad is especially strong, among the students. They consider this criterion as the most important while choosing universities/colleges.

It is true that the lack of prospects in finding a suitable job forces the youth to emigrate in search for work. However, for a substantial number of them it is only acceptable to work with their own occupation. On top of that, the youth's attitude toward illegal work has changed drastically. If ten years ago the majority of the respondents thought such a job to be acceptable, today, on the contrary, illegal job is categorically unacceptable for most of them.

During the last ten years, the quantity of those students who intend to leave the homeland forever has increased 1.4 times. If the quantity of such students continues to grow at 
such rate, this will reflect in a negative manner not only on the demographic processes of the country, but also on its economic situation.

\section{REFERENCES}

1. Urgent problems of the migration of population in Georgia. Collective monograph. (2018). Publication of the Institute of Demography and Sociology of Ilia State University. Tbilisi. P. 10-11 [in Georgian].

2. Hakkert, R. (2017). The dynamics of population in Georgia, review based on the results of the 2014 general population census of Georgia. Tbilisi. P. 61-69. Retrieved from https://georgia.unfpa.org

3. Geostat geostat.ge. Retrieved from www.geostat.ge

4. Archvadze, I. (2018). Labor emigration. Urgent problems of migration in Georgia. Collective monograph. Publication of the Institute of Demography and Sociology of Ilia State University. Tbilisi. P. 157. [in Georgian].

5. Eelens, F. (2017). Youth in Georgia. Review based on the results of the 2014 general population census of Georgia. Tbilisi. 2017. P. 52-57. Retrieved from https://georgia.unfpa.org/ka/publications

6. Calhoun, C., Light, D., \&Keller, S. (2008). Sociology. Ilia State University. Tbilisi. P. 636-637; 644 [in Georgian].

7. Chelidze, N. (2008). Study-labor migratory attitudes of the students of Georgia's higher educational institutions. Migration, 2, 103.Tbilisi [in Georgian].

8. Hakkert, R., \&Sumbadze, N. (2017). Analysis of the results of the 2014 general population census of Georgia in terms of gender. Tbilisi. P. 71-76. Retrieved from https://georgia.unfpa.org

9. Sulaberidze A., Archvadze, I., \&Sulaberidze, V. (2018). The migration and potential of Georgian population from the period of gaining independence until today. Economisti, 3, 7-25. Retrieved from http://pgie.tsu. ge/index.php? menuid=17\&lang $=1 \& \mathrm{id}=5$

Article submitted on 10.07.2019

Стаття надійшла до редакції 10.07.2019 